UDK: 173.7

159.973-053.5

Prethodno priopćenje

Primljen 19. X. 2019

Maja Nižić - Tanja Penava - Marijana Mutabdžić

Filozofski fakultet Sveučilišta u Mostaru - Županja

maja.nizic@ff.sum.ba - tanja.penava@ff.sum.ba -

marijana.mutabdzic@gmail.com

\title{
ISKUSTVA RODITELJA DJECE S INTELEKTUALNIM TEŠKOĆAMA U KOMORBIDITETU S ADHD-OM
}

\section{Sažetak}

U Bosni i Hercegovini malo je saznanja o iskustvima roditelja djece s intelektualnim teškoćama kod kojih je prisutan i ADHD. Cilj je ovoga istraživanja dobiti uvid $u$ iskustva tih roditelja kroz istraživačka pitanja koja se odnose na proces prihvaćanja dijagnoze, iskustva podrške te doživljaja svoje ulogu u životu djeteta. Analiza rezultata pokazala je kako roditelji doživljavaju neugodne emocije i neizvjesnost pri suočavanju s dijagnozom. U svrhu suočavanja mobiliziraju različite osobne mehanizme. Formalni izvori podrške, obitelj i podrška šire okoline važni su pri suočavanju sa svakodnevnim izazovima, a dio roditelja suočava se i s nedostatkom socijalne podrške. Svoju ulogu vide kroz posvećenost odgoju djeteta i zadovoljavanje djetetovih potreba. Na temelju rezultata istraživanja može se zaključiti kako je potrebno raditi na senzibilizaciji javnosti za brojne probleme s kojim se susreću roditelji djece s intelektualnim teškoćama i ADHD-om te omogućiti kvalitetnije i dostupnije usluge koje će biti kreirane prema potrebama tih obitelji.

Ključne riječi: roditelji djece s intelektualnim teškoćama; ADHD; podrška; suočavanje 


\section{Uvod}

Intelektualne teškoće definiraju se kao neurorazvojni poremećaj koji nastaje prije 18. godine života. Osobe s intelektualnim teškoćama iskazuju ispodprosječno intelektualno funkcioniranje i bitno ograničenje adaptivnoga funkcioniranja koje se odnosi na različite svakodnevne konceptualne, socijalne i praktične vještine (usp. Schalock i dr., 2007). Djeca s intelektualnim teškoćama sklonija su mentalnim poremećajima među kojima se navodi i ADHD (usp. Neece i dr., 2013). ADHD označava poremećaj koji se u hrvatskoj stručnoj literaturi naziva nedostatak pažnje/hiperaktivni poremećaj, a sama skraćenica AD/HD dolazi od engleskoga termina Atention Defficit and/or Hyperactivity Disorder. Obično se očituje između treće i četvrte godine života. Kod neke djece simptomi mogu biti vidljivi već u ranome djetinjstvu, kod druge tek u petoj ili šestoj godini života, a pokazalo se kako se prenosi čak i u odraslu dob kod 30-70 \% slučajeva (usp. Hughes - Cooper, 2009). Istraživanja ADHD-a pokazuju kako se rijetko javlja kao izolirani poremećaj te obično postoji u komorbiditetu s drugim razvojnim poremećajima i stanjima (usp. Larson i dr., 2007; Jensen Martin - Cantwell, 1997).

Simptomi koji najčešće opisuju ADHD su nepažnja, impulzivnost i hiperaktivnost. Specifične smetnje u pažnji i ponašanju koje se manifestiraju u različitim okolinskim uvjetima mogu biti (usp. Hughes - Cooper, 2009):

- obrazac ponašanja koji odvlači njihovu pažnju i pažnju ljudi oko njih

- poteškoće u zadržavanju pažnje na zadatcima i aktivnostima

- poteškoće u započinjanju i dovršavanju zadataka i aktivnosti

- ostavljaju dojam da ne reagiraju na verbalne upute

- ostavljaju dojam da su neorganizirani i zaboravni

- ostavljaju dojam da imaju nezreo pristup aktivnostima.

Istraživanja pokazuju kako su djeca s intelektualnim teškoćama rizičnija za pojavu ADHD-a nego vršnjaci bez intelektualnih teškoća (usp. Neece i dr., 2013), no Fuller i Sabatino (1998, prema Ahuja - Langley 
- Thapar, 2013) ukazuju na problem koji nazivaju „dijagnostičko zasjenjivanje“, odnosno sklonost kliničara da zanemaruju dodatne psihijatrijske dijagnoze nakon postavljanja dijagnoze intelektualnih teškoća. Tako simptomi ADHD-a nerijetko ostaju maskirani kognitivnim, jezičnim ili govornim oštećenjima vezanim uz intelektualne teškoće. Ahuja i dr. (2013) ističu kako djeca s intelektualnim teškoćama u kombinaciji s ADHD-om iskazuju puno više simptoma poremećaja u ponašanju i poremećaju protivljenja i odbijanja od djece s intelektualnim teškoćama bez kombinacije s ADHD-om (Ahuja i dr., 2013). Očito je kako su posljedice za funkcioniranje djeteta s intelektualnim teškoćama, a i brigu o njemu, time znatno složenije.

\section{Iskustva roditelja djece s intelektualnim teškoćama i ADHD-om}

Razvojne teškoće djeteta mogu biti velik stresor za roditelje. Tako odgoj djeteta s intelektualnim teškoćama za roditelje može biti iscrpljujuće i stresno iskustvo, praćeno obiteljskim konfliktima i strahovima za budućnost djeteta, osobito za majke koje su najčešće posvećene brizi djeteta (usp. Willingham-Storr, 2014). Rezultati istraživanja pokazuju da je kod majki djece $s$ intelektualnim teškoćama prisutna bitno veća razina stresa kao i veća sklonost anksioznosti i depresiji nego kod majki djece bez teškoća u razvoju (usp. Emerson, 2003; Lee, 2013; Totsika i dr., 2011, prema McConnell - Savage, 2015). Također, kod roditelja djece s ADHD-om zabilježena je povećana razina stresa (usp. Yousefia - Far Abdolahianb, 2011; Theule i dr., 2010). To je zato što ponašanje djeteta $s$ ADHD-om odstupa od uobičajenih normi ponašanja, zbog čega dolazi do nesklada u odnosima s okolinom. Primjerice, Timmermanis i Wiener (2011) navode kako djeca s ADHD-om imaju teškoća u interakciji s okolinom te se pokazalo kako su češći sudionici vršnjačkoga nasilja nego djeca bez ADHD-a, i to u obje uloge, kao žrtve, ali i kao nasilnici. Njihovi roditelji i učitelji ukazuju na više problema u vršnjačkim odnosima, a sami sebe percipiraju kao osobe koje imaju nižu vršnjačku i obiteljsku podršku nego adolescenti bez ADHD-a. Jedno domaće istraživanje 
provedeno u Hrvatskoj također upućuje na veću razinu agresivnosti, nasilja, ali i viktimizacije kod djece s izraženijim simptomima (Velki Dudaš, 2016).

Iskustva roditelja djece s intelektualnim teškoćama i ADHD-om govore o doživljaju negativne percepcije okoline. Ako je ADHD prisutan kod djeteta kao izolirani poremećaj, bez drugih vidljivih fizičkih obilježja koja upućuju na to da se radi o djetetu s razvojnim teškoćama, okolina ne pokazuje razumijevanje ni suosjećanje prema roditeljima te ih obilježava kao nesposobne. Svakodnevno funkcioniranje time je otežano jer su roditelji često izloženi takvoj stigmatizaciji (Cosser, 2005; dos Reis i dr, 2010). Čak i ako ADHD postoji u komorbiditetu, roditelji se susreću s etiketiranjem djeteta, odnosno označavanjem djeteta kao problematičnoga. Takva percepcija djeteta usko je vezana za socijalnu izolaciju koju roditelji osjećaju u krugu obitelji, škole i širega društva (dos Reis i dr., 2010). Peters i Jackson (2008) kod roditelja identificiraju postojanje emocionalnih teškoća u obliku osjećaja krivnje zbog postojanja poremećaja kod djeteta, ali i teškoće u odnosima s okolinom i profesionalcima zaduženima za brigu o djetetu. Cosser (2005) navodi još i postojanje osjećaja srama zbog djetetova ponašanja u različitim okruženjima i društvenim aktivnostima te osjećaj tuge zbog gubitka predodžbe o idealnome životu s djetetom kakav su zamišljali. Triwitz i Golubchik (2011, prema Bartolac, 2013, 280) objašnjavaju razloge veće razine stresa kod roditelja i specifične teškoće s kojima se susreću roditelji prilikom odgoja svoje djece s ADHD-om. Tako navode smanjeno zadovoljstvo i povjerenje u vlastite roditeljske vještine, povišen roditeljski stres i neslaganje, smanjen osjećaj roditeljske sposobnosti, nisko očekivanje uspjeha $\mathrm{u}$ odgoju vlastite djece te povišenu razinu roditeljskoga stresa i psihopatoloških simptoma roditelja, osobito u slučaju kada se uz ADHD komorbidno javljaju problemi u ponašanju.

Uslijed povećanoga stresa roditelji nerijetko imaju manji kapacitet za pružanje odgovarajuće podrške djetetu. Kapacitet je još manji ako su kod djeteta jako izraženi simptomi ADHD-a što povećava roditeljski stres, a osobito su pri tome ugroženi samohrani roditelji (usp. Theule i dr., 2010) jer je često upravo bračni partner primarni izvor podrške 
(usp. Cosser, 2005; Willingham-Storr, 2014). Ako obitelj nema kapacitet nositi se sa stresorima, obiteljski sustav je ugrožen. Stoga su roditeljima potrebni programi podrške na različitim razinama kako bi mogli odgovoriti na djetetove potrebe i očuvati vlastito mentalno zdravlje. Istraživanja pokazuju kako podrška i pomoć koju roditeljima pružaju članovi njihove socijalne mreže uvelike doprinosi konstruktivnoj roditeljskoj praksi u odnosu prema djeci, pozitivnim ishodima za dijete (usp. Cochran - Walker, 2005) i boljoj kvaliteti života obitelji.

U Bosni i Hercegovini nema dostupnih istraživanja koja se bave iskustvima roditelja djece s intelektualnim teškoćama koji uz to imaju dijagnozu ADHD. Stoga je ovaj rad doprinos razumijevanju iskustava roditelja u domaćem kontekstu, ali i usmjeravanju stručnjaka i šire javnosti na ona područja gdje roditeljima nedostaje podrška.

\section{Cilj i straživačka pitanja}

Osnovni je cilj ovoga istraživanja dobiti uvid u neke aspekte iskustva roditelja djece s intelektualnim teškoćama u komorbiditetu s ADHD-om.

U skladu s tim ciljem postavljena su sljedeća istraživačka pitanja:

1) Kako roditelji opisuju proces prihvaćanja dijagnoze?

2) Kakva su iskustva podrške roditelja?

3) Kako roditelji doživljavaju svoju ulogu u životu djeteta?

\section{Metodologija}

\subsection{Sudionici istraživanja}

U istraživanju se koristio namjerni uzorak koji se najčešće koristi u kvalitativnim istraživanjima, jer samo takvi uzorci omogućuju prikupljanje informacija ključnih za razumijevanje pojave koja se istražuje (usp. Milas, 2009). Sudjelovalo je ukupno sedam roditelja djece s intelektualnim teškoćama koji imaju dijagnosticiran i ADHD. Od sedam sudionika pet je majki i dva oca. Sudionici su kontaktirani preko lokalnih 
udruga roditelja djece s teškoćama u razvoju s područja Orašja, Šamca, Grebnica i Odžaka. Prosječna je starost sudionika 40 godina. Najmlađi sudionik imao je 27, a najstariji 46 godina. Tri sudionika imaju završenu osnovnu školu, tri imaju srednju stručnu spremu, a jedan sudionik ima visoku stručnu spremu. Tri su sudionika u radnome odnosu, a četiri su nezaposlena. Svi su sudionici u braku, njih šest ima dvoje djece, a jedan osmero djece.

\subsection{Postupak provedbe istraživanja}

Istraživalo se od rujna do studenoga 2017. godine na području Orašja, Šamca, Grebnica i Odžaka. Korištena je metoda polustrukturiranoga intervjua koja je primjerena za dobivanje uvida $\mathrm{u}$ iskustva sudionika $\mathrm{i}$ značenje koje to iskustvo ima za njih (usp. Seidman, 2006). Prilikom stupanja u kontakt $\mathrm{s}$ mogućim sudionicima objašnjeni su tema, svrha i cilj istraživanja, zajamčena je anonimnost i povjerljivost podataka. Tijekom provođenja intervjua prisutni su bili samo intervjuer i sudionik. Pojedini intervju trajao je prosječno 1 sat. Audiomaterijal transkribiran je u kratkome vremenskom intervalu nakon svakoga intervjua. Po transkribiranju audiosadržaja pristupilo se obradi podataka. Svakomu sudioniku dodijeljen je kodni broj kako bi se zaštitio njegov identitet te se na taj način mogu pratiti izjave koje pripadaju istoj osobi.

\subsection{Obrada podataka}

$\mathrm{Za}$ analizu prikupljenih podataka $\mathrm{u}$ ovome istraživanju koristila se induktivna tematska analiza koja je prikladna za dobivanje bogatoga, detaljnoga i složenijega prikaza fenomena (usp. Braun - Clarke, 2006). Tematska analiza metoda je za identifikaciju, analizu i interpretaciju obrazaca (tema) koje se pojavljuju u analiziranju izjava ili tekstova. Provedena je u šest koraka, onako kako sugeriraju Braun i Clarke (2006). Prva faza bila je upoznavanje sa setom podataka kroz sami postupak intervjuiranja, transkribiranje te opetovano čitanje cjelokupnoga materijala. Drugi korak je inicijalno kodiranje, odnosno organiziranje podataka u smislene kategorije. Induktivna tematska analiza znači da su 
kodovi proizišli iz samih podataka. Nakon izdvajanja većega broja kodova, pristupilo se razvrstavanju istih u moguće teme što čini treći korak analize. Za svako istraživačko pitanje definirane su glavne teme s pripadajućim kodovima te su izdvojeni citati iz podataka koji potkrjepljuju svaki kod. Četvrta faza analize podrazumijeva provjeru definiranih tema kroz usporedbu s kodovima is cijelim setom podataka te stvaranje tematske mape. Sljedeća faza je definiranje i precizno imenovanje svake teme koja je predstavljena u rezultatima. Zadnja, šesta faza izvještavanje je o rezultatima, pri čemu je važno da analiza i sami izvještaj sadrže dijelove transkribiranoga teksta i pružaju jezgrovitu, dosljednu, logičnu i zanimljivu priču o podatcima. Na taj su način prikazani rezultati u ovome radu.

\section{Rezultati i rasprava}

Kvalitativnom analizom provedenih intervjua dobiveni su podatci koji govore o iskustvima roditelja djece $\mathrm{s}$ intelektualnim teškoćama $\mathrm{u}$ komorbiditetu s ADHD-om. Slijedi prikaz tema koje opisuju kako su roditelji prolazili kroz proces prihvaćanja dijagnoze, kakva su njihova iskustva socijalne podrške kao i njihovo razumijevanje vlastite uloge $u$ životu djeteta.

\subsection{Kako roditelji opisuju prihvaćanje djetetove dijagnoze?}

Tablica 1. Teme i kodovi o roditeljskome iskustvu prihvaćanja dijagnoze djeteta

\begin{tabular}{|l|l|}
\hline TEME & KODOVI \\
\hline Doživljavanje neugodnih emocija & Razočarenje \\
& Tuga \\
& Uznemirenost \\
& Strah \\
& Zabrinutost \\
\hline Mehanizmi suočavanja s dijagnozom & Posvećenost skrbi za dijete \\
& Religioznost \\
& Samoohrabrivanje \\
\hline
\end{tabular}

Teme opisuju iskustvo roditelja pri suočavanju s dijagnozom kao proces 
obilježen doživljavanjem neugodnih emocija, neizvjesnošću te postojanjem mehanizama suočavanja s dijagnozom.

\subsubsection{Doživljavanje neugodnih emocija}

Sudionici su iskazali osjećaj razočarenja: „Možda je bilo malo razočarenja.“ (1), „Bilo mi je krivo...“ (2), „Nije mi jednostavno bilo, meni je krivo...“ (3), „Osjećaš se razočarano." (4), „Bilo je pitanje: Zašto mi? (7); tuge: „...jako tužno...“ (2), „Bila sam tužna...“ (6), „Tuga...“ (4); uznemirenosti koja se odnosi na osjećaj psihičkoga i fizičkoga nemira: „Bio mi je veliki stres, plakala sam, mene je to pogodilo.“ (3), „Bio je veliki šok..." (6), „Isprava me pogađalo, bila sam frustrirana, ljuta..." (2), „Dolazilo mi je da poludim u svemu tome... Imala sam nesanice, nervozna sam jako bila... Bilo mi je uznemirujuće“ (4) kao i straha: „S vremenom je preraslo u veliki strah“ (6), „Bili smo jako prepadnuti..." (3), „Osjećaj straha je bio“ (5). Iskustva roditelja podudaraju se s onima zabilježenim i u drugim istraživanjima gdje su kod roditelja djece s teškoćama u razvoju također izražavali postojanje snažnih neugodnih emocija, osobito ljutnje, krivnje i tuge (usp. Taylor, 1999). Većina roditelja doživljava tugu (usp. Kearney - Griffin, 2001; Graungaard - Skov, 2006) te tako zapravo prolaze svojevrsni proces tugovanja za „idealnim djetetom“ (Cosser, 2005). Kandel i Merrick (2003) slično objašnjavaju kako ove reakcije proizlaze iz procesa prihvaćanja činjenice da dijete neće ispuniti nade i ambicije koje su gajili do tada. Također se i suočavaju s velikim promjenama u obiteljskome i društvenome životu, što izaziva frustraciju i razočarenje. Dakle, stres, osjećaj tuge, ljutnje, šok, osjećaj krivnje emocionalne su reakcije koje prate proces prihvaćanja djetetove dijagnoze i u drugim istraživanjima (usp. Heiman, 2002; Kandel - Merrick, 2003).

Roditelji ističu i zabrinutost koju su osjećali na početku. To objašnjavaju postojanjem brige za dijete, odnosno snažnom zabrinutošću za budućnost: „Htjela sam da je on dobro i siguran, bilo je stresnih i teških trenutaka..." (1), „Bio sam zabrinut...bilo mi je teško.“ (5), „...zabrinutost...“ (4). Zabrinutost je rezultat i neznanja, odnosno neimanja informacija o samoj dijagnozi, njezinim implikacijama i potrebnim intervencijama 
(„Nisam znala što ću..." (2), „Nisam znala kako da se nosim s tim..." (6)). I u drugim istraživanjima roditeljima su zajednički osjećaji zabrinutosti, osobito za budućnost djeteta (usp. Kearney - Grifin, 2001), i zbunjenosti (usp. Heiman, 2002). Slična iskustva nalazimo u istraživanju Lin, Huang i Hung (2009, prema Bartolac, 2013) koji ističu kako se emocionalni teret nošenja sa situacijom kod roditelja odražavao u osjećajima frustriranosti, bespomoćnosti, ljutnje i zabrinutosti. Pri tome majke često izjavljuju kako nemaju dovoljno kapaciteta nositi se s djetetovim ponašanjem, a zbog nedostatka informacija ne znaju što bi trebale činiti niti imaju informaciju gdje mogu dobiti podršku i pomoć. Roditelji pri dobivanju dijagnoze trebaju informacije o djetetovu stanju, a količina i kvaliteta informacija koju pružaju zdravstveni djelatnici može pomoći roditeljima u nošenju s početnom brigom za budućnost i neizvjesnošću koju ona donosi (usp. Graungaard - Skov, 2007).

\subsubsection{Mehanizmi suočavanja s dijagnozom}

Rezultati ovoga istraživanja pokazuju kako dio roditelja, unatoč emocionalnomu stanju koje prolaze i neizvjesnosti s kojom se suočavaju, pokazuje i pozitivno prihvaćanje situacije. Roditelji koriste različite mehanizme za suočavanje s trenutnom situacijom i nošenjem s izazovima. Za jedan dio roditelja to je bila posvećenost skrbi djeteta: „Trudit ću se pomoći mu, sve sam se borila za njegovo dobro." (3), „Nije mi teško za njega ništa.“ (7), „Kad vidiš da sam ja njezin oslonac u svemu i da joj pružam ljubav..." (4); „Zadovoljstvo mi je biti roditelj djetetu. Dajem sve od sebe." (5).

Nadalje, religioznost roditelja pokazala se jako važnom za dvoje sudionika u procesu prihvaćanja dijagnoze: „Vjera mi je pomogla u Boga“" (3), "Jačala sam sama sebe, uzdala sam se u Boga, molitva mi je značila..." (4). U istraživanju koje je proveo Hrvatski savez Udruga tjelesnih invalida 2003. godine također se ističe vjera kao izrazito važan oblik podrške roditeljima (usp. Leutar - Ogresta - Milić-Babić, 2008) te kao vrlo važan faktor $u$ nošenju sa stresnim situacijama, vezanim uz invaliditet i druge stresne situacije (usp. Leutar - Ogresta - Milić-Babić, 
2008). Bhan, Mehta i Chhaproo (1998, prema Gupta - Singhal, 2004) su u istraživanju u kojem su sudjelovale majke djece s cerebralnom paralizom utvrdili kako su majčine crte ličnosti, optimizam i religioznost činitelji ublažavanja stresa. Pozitivan stav i religioznost pokazali su se kao generatori psihičke snage za suočavanje s fizičkim, emocionalnim i financijskim aspektima skrbi za dijete (usp. Bhan i dr. 1998, prema Gupta - Singhal, 2004). Dva sudionika ističu samoohrabrivanje koje se očituje vjerom u prolaznost simptoma, ali i prihvaćanjem trenutne situacije uz nadu da se stanje neće pogoršati u odnosu na trenutno: „Mislila sam da će proći tijekom puberteta, ali nije.“ (...) „Ohrabrivala sam se." (4), „Govorio sam uvijek: Ne daj, Bože, gorega." (5), „Sama sam sebi najveća podrška." (3). Cosser (2005) također navodi kako roditelji djece s ADHD-om koriste pozitivno razmišljanje uz ostale strategije kao što su prihvaćanje djeteta kakvo jest, proaktivno djelovanje, ustrajnost i sl. u nošenju s djetetovim ponašanjem i svakodnevnim izazovima koji su pred njima. Chang i McConkey (2008) govore o iskustvima roditelja djece s intelektualnim teškoćama koji su se suočavali s dijagnozom tako što su pokušavali prihvatiti invaliditet i posljedice na obitelj. Pri tome su navodili optimistično sagledavanje situacija, usmjeravanje na sposobnosti više nego na ograničenja, razvijanje realističnih očekivanja i sl. Graungaard i Skov (2007) tomu dodaju prikupljanje informacija, učenje novih vještina, istraživanje mogućnosti alternativne medicine, traženje drugoga mišljenja i sl. Strategije emocionalnoga suočavanja koje su identificirali isti autori su zadržavanje nade, stvaranje slike budućnosti, ignoriranje ozbiljnosti problema, usmjeravanje na mogućnosti djeteta i identificiranje pozitivnih aspekata situacije. 


\subsection{Kakva su iskustva podrške roditelja djece s teškoćama u razvoju u komorbiditetu s ADHD-om?}

Tablica 2. Teme i kodovi o iskustvu podrške roditelja

\begin{tabular}{|l|l|}
\hline TEME & KODOVI \\
\hline Formalni izvori podrške & Djelatnici lokalne udruge \\
& Ustanove u lokalnoj zajednici \\
Zdravstveni djelatnici
\end{tabular}

Generirane teme ukazuju na postojanje podrške iz nekoliko izvora: formalna podrška, podrška uže obitelji i šire zajednice, no iskustva sudionika također su obilježena i nedostatkom socijalne podrške.

\subsubsection{Formalni izvori podrške roditeljima}

Moran, Ghate i van der Merwe (2004) u svojem istraživanju ističu kako socijalna podrška ima snažan zaštitni učinak od stresa. Važnost podrške, osobito u kriznim situacijama, vidljiva je kroz praksu jaslica, vrtića, raznih udruga, vjerskih organizacija i sl. Kroz mogućnosti odabira skrbi za dijete, koje se također smatraju podrškom obitelji, roditelji imaju mogućnost zadovoljiti svoje druge potrebe poput potrebe za radom, druženjem s partnerom, prijateljima ili pak za opuštanjem. Isti autor pod formalnim izvorima podrške udruge navodi lokalnu zajednicu, vjerske i druge organizacije civilnoga društva. Analizom odgovora sudionika u ovome istraživanju mogu se prepoznati izvori formalne 
podrške: djelatnici lokalne udruge: „Udruga i njezini djelatnici su mi najviše pružali psihološku pomoć.“ (1), „Mogu samo reći: udruga je jedina i podrška mi bila... od ostalih nema ništa..." (6); ustanove u lokalnoj zajednici: „Bilo mi je dobro, pa ima vrtić, ima asistenta koji ga smiri.“ (2), ,Velika podrška mi je rehabilitacijski centar..." (6) i zdravstveni djelatnici: „Veliku podršku mi daje neuropedijatar, logoped i defektolog." (7), Podršku mi je najveću pružio razgovor sa psihologom.“ (2), „Najveća podrška mi je bio razgovor s doktorom i defektologom..." (2)). Roditelji zapravo ističu one stručnjake u zdravstvenome sustavu u čijem se tretmanu dijete nalazi. Rezultati drugih istraživanja pokazuju kako je komunikacija između zdravstvenih stručnjaka i roditelja za vrijeme procesa postavljanja dijagnoze jako važna i može donekle odrediti način na koji se roditelji suočavaju s dijagnozom. Međutim, roditelji su često nezadovoljni i kritiziraju upravo zdravstvene djelatnike u smislu da nisu imali takvu podršku od njih (usp. Graungaard - Skov, 2007). Strehle i Middlemiss (2007) također navode iskustva roditelja gdje su pri doznavanju dijagnoze bili pod velikim stresom te su uz to osjetili nedostatak dostupnih medicinskih informacija. Willingham-Storr (2014) u pregledu istraživanja zaključuje kako roditelji i obitelji imaju svoje snage, ograničenja i mehanizme suočavanja, no mnogi osjećaju kako ne primaju odgovarajuću razinu podrške od zdravstvenih djelatnika. Iako su se roditelji, sudionici ovoga istraživanja, suočavali s nedostatkom informacija u nekim trenutcima, ipak su zdravstveni djelatnici istaknuti kao važan segment formalnih izvora podrške roditeljima. Osim stručnjaka u zdravstvenome sustavu, lokalna udruga i ustanove u lokalnoj zajednici za roditelje su izvor formalne podrške. Istraživanje provedeno u Hrvatskoj pokazuje kako su udruge zaista važan dio mreže podrške roditeljima djece s teškoćama u razvoju koje roditelji koriste čak učestalije nego formalne izvore podrške (Leutar - Oršulić, 2015). Roditelji, ali i cijele obitelji djece s teškoćama u razvoju podložne su stresu svakodnevne brige i skrbi za dijete. U takvoj je situaciji roditeljima potrebna podrška, ponajprije u suočavanju s razvojnim teškoćama vlastitoga djeteta, a onda i podrška i usmjeravanje u tome kako se ponašati, što poduzeti i komu se obratiti za pomoć (usp. Leutar - Ogresta - Milić-Babić, 2008). 


\subsection{2. Članovi obitelji kao izvor podrške}

Osim formalnih izvora, sudionici navode obitelj kao važan izvor podrške. Pri tome navode članove obitelji: „Podrška mi je moja obitelj...” (1), „Najveću podršku imam od svoje obitelji.“ (6), „Meni je moja obitelj najveća podrška." (7), „Obitelj i ja si međusobno pružamo podršku...” (7); bračnoga partnera: „Moj suprug mi je podrška““ (6), „Muž mi je jedina potpora..." (3), „Najveća podrška mi je moja supruga." (5); braću: „Najveću podršku sam dobivala i od svojeg brata.“ (3), „Podršku su mi davali moja braća..." (4); kći: „Moj mali anđeo mi je najveća podrška.” (4), „Moja kći mi je velika podrška.“ (6) i roditelje: „Podršku su mi davali moji roditelji." (4), „Moji roditelji su mi najveća podrška“" (1).

Ovi rezultati potvrđuju nalaze i drugih istraživanja o obitelji kao primarnome izvoru različitih oblika podrške (usp. Sen - Yurtsever, 2007; Heiman, 2002). Istraživanje Leutar i Oršulić (2015) pokazalo je kako roditelji djece $s$ teškoćama u razvoju najčešće dobivaju emocionalnu, financijsku, praktičnu i savjetodavnu pomoći unutar obitelji te da je supružnička podrška najvažnija i najizraženija (usp. Leutar - Oršulić, 2015, Cosser, 2005; Chang - McConkey 2008). Sen i Yurtsever (2007) ističu kako majke najviše emocionalne podrške dobivaju od članova obitelji, no ta podrška nije dovoljna za prorađivanje emocionalnih kriza. Navedeno se može povezati s prethodnim nalazom ovoga istraživanja o važnosti formalnih izvora podrške kao dopuni obiteljskoj podršci. Heiman i Berger (2008) ukazuju na potrebu roditelja za kombiniranjem više izvora podrške u srbi za dijete s teškoćama u razvoju, pa tako koriste podršku uže obitelji koju nadopunjuju podrškom obrazovnoga sustava, nevladinoga sektora i drugih usluga u lokalnoj zajednici.

\subsubsection{Podrška šire okoline}

Sudionici ovoga istraživanja također su identificirali osobe iz šire okoline kao izvore podrške te su među njima naveli roditelje druge djece $\mathrm{s}$ teškoćama u razvoju: „Veliku podršku dobivam od drugih roditelja sa istim problemom.“ (2); osobe iz lokalne zajednice: „Neki susjedi su mi davali podršku, mislili su da sam jaka..." (4), „Veliku podršku imam od 
susjeda i kroz cijeli period koji prolazimo uveliko nam je pomogla i župna zajednica, bila mi je velika podrška.“ (6); ,,Moja okolina i zajednica u kojoj živimo daju mi podršku, zahvaljujući tim ljudima dosta dobro se snalazimo.“ (7), a jedan je sudionik naveo i bliske prijatelje: „Moji bliski prijatelji su mi najveća podrška." (6).

Opisujući iskustva roditelja djece s ADHD-om, slične rezultate donosi i Cosser (2005) gdje je nekoliko sudionika pridalo veliku važnost prijateljima i roditeljima druge djece sa sličnim teškoćama i dijeljenju iskustava kroz grupe podrške, osobito za roditelje koji tek ulaze u proces dijagnosticiranja ili prihvaćanja dijagnoze. Međusobna podrška roditelja djece s teškoćama u razvoju pokazala se važnom ponajprije jer mogu učiti jedni od drugih dijeleći vlastita iskustva. Drugi razlog tomu jest to što su roditelji prepoznali da se u odnosu s drugim roditeljima osjećaju ravnopravni i lišeni diskriminacije koju osjećaju u svojoj okolini (usp. McCabe, 2008). Za roditelje djece s intelektualnim teškoćama podrška obitelji i prijatelja u obliku ohrabrenja može biti od veće pomoći nego podrška koju dobivaju od profesionalaca (usp. Chang - McConkey, 2008). Rezultate potvrđuje i istraživanje autora Heiman i Berger (2008) koji ističu važnost izvora socijalne podrške izvan obitelji kao i potrebe za učinkovitim programima roditeljske podrške. Obitelj primarno crpi vlastite resurse $u$ nošenju sa svakodnevnim zahtjevima skrbi za dijete i pri tome koriste aktivne strategije, no oslanjanje na obitelj dovodi do crpljenja obiteljskih resursa te se javlja potreba za drugim izvorima podrške (usp. Milić Babić - Laklija, 2013, 219).

\subsubsection{Nedostatak socijalne podrške}

Do sada je više puta naglašena važnost postojanja socijalne podrške za roditelje djece s teškoćama u razvoju. Kako postojanje socijalne podrške ima pozitivne učinke za roditelje, logično je da nedostatak socijalne podrške produbljuje svakodnevne probleme. S obzirom na stalni napor i skrb oko djeteta te preuzimanje na sebe kritike usmjerene na dijete, roditelji mogu iscrpiti svoje adaptivne resurse zbog prezahtjevnosti situacije u kojoj se nalaze (usp. Bartolac, 2013.). Dio sudionika ovoga 
istraživanja iskusio je nedostatak socijalne podrške ponajprije u obliku izbjegavanja: „Od susjeda i okoline nisam imala nikakvu podršku, oni su ga izbjegavali..." (1); „Uvijek su govorili da njega ne vodi, bio je nepoželjno dijete za moje susjede.“(2), „Pokušala sam razgovarati, ali kako su njega izbjegavali, tako su i mene." (3).

Sudionici i otvoreno i suptilno iskazuju da ih drugi ljudi izbjegavaju, zbog čega je produbljen osjećaj nepoželjnosti u društvu. Druga istraživanja opisuju slična iskustva roditelja djece s ADHD-om i osjećaj izolacije i odbacivanja od obitelji, ali i lokalne zajednice (usp. Peters - Jackson, 2008; DosReies i dr., 2010 ; Chang - McConkey, 2008). Kod majki je osobito naglašena iscrpljenost zbog zahtjevnosti djetetova ponašanja uz istovremenu minimalnu pomoć obitelji, prijatelja i lokalne zajednice (usp. Peters - Jackson, 2008). Poražavajući je podatak da su roditelji doživjeli nerazumijevanje i nepostojanje podrške i u školi: „Obrazovanje je bilo nula.“ (1), „Nikakva što se tiče škole...“ (1), „Škola nije dopuštala da ide po prilagođenom programu.“ (1), ,Ravnatelj srednje škole ga nije htio upisati u školu.“ (1), „Bilo je stresnih i teških trenutaka...“ (1), „Škola nije htjela raditi s njim." (3), što objašnjavaju time da škola ili nije dopustila upisivanje djeteta ili je samo obrazovanje bilo niske kvalitete po procjeni roditelja.

Drugačija iskustva roditelja djece s teškoćama u razvoju prikazuju Leutar i Oršulić (2015) gdje se pokazalo kako roditelji, iako je rijetko traže, najčešću podršku dobivaju od škole i vrtića. Iskustva roditelja $s$ uključivanjem djeteta u obrazovni sustav svakako ovise o spremnosti i osviještenosti školskoga vodstva za potrebe uključivanja učenika $s$ ADHD-om (i drugim razvojnim teškoćama i poremećajima), ali i resursima škole koji odgovaraju na obrazovne potrebe djeteta sa svim njegovim karakteristikama.

Nadalje, dio roditelja nema podršku ni u obitelji: „Od rodbine zadobivam najveće poteškoće, nemam od njih nikakvu podršku““ (2), „Nedostatka podrške od strane supruga... muževa sebičnosti mi je otežavala.“ (4), „Neshvaćenost od obitelji, nitko me nije razumio." (2). U ovome istraživanju, dakle, dvojaka su iskustva roditelja s obiteljskom podrškom, s jedne strane roditelji u prethodnim temama iskazuju obitelj kao važan 
izvor podrške, a s druge strane - to nije iskustvo svih roditelja. Cosser (2005) također opisuje dvojaka iskustva roditelja pri čemu je bilo onih koji su doživjeli pozitivno iskustvo podrške uže i šire obitelji, ali i onih kojima su članovi šire obitelji prouzrokovali stres vlastitim ponašanjem ili izjavama koje su se odnosile na dijete. Slično opisuje i istraživanje Kearney i Griffin (2001) u kojem su sudionici osjetili nedostatak podrške kroz dobivanje negativnih poruka o djetetu od obitelji i prijatelja, ali i kroz beznadne prognoze liječnika. Roditelji su se zbog takvih poruka osjećali izolirano i odbačeno. Istražujući roditeljska iskustva, Hallberg i dr. (2008) prikazuju temu koja se pojavljivala u razgovorima s roditeljima, a nazivaju je „život na rubu kapaciteta“. Kao i teme koje su iznijeli sudionici ovoga istraživanja, roditelji su istaknuli osjećaj izolacije i napuštenosti, nedostatak podrške, a uz to i usamljenost u borbi za profesionalnu podršku, pokušaj razrješavanja obiteljskih konflikta i težinu obavljanja roditeljske dužnosti 24 sata na dan.

\subsection{Kako roditelji doživljavaju svoju ulogu u djetetovu životu?}

Tablica 3. Teme i kodovi o roditeljskome doživljaju svoje uloge u djetetovu životu

\begin{tabular}{|l|l|}
\hline TEME & KODOVI \\
\hline Posvećenost odgoju djeteta & $\begin{array}{l}\text { Podučavanje vještina za život } \\
\text { Požrtvovno roditeljstvo }\end{array}$ \\
\hline Zadovoljavanje djetetovih potreba & $\begin{array}{l}\text { Emocionalna sigurnost djeteta } \\
\text { Briga za zdravstveno stanje } \\
\text { Briga za materijalnu sigurnost }\end{array}$ \\
\hline
\end{tabular}

\subsubsection{Posvećenost odgoju djeteta}

Posvećenost odgoju djeteta iskazana je ponajprije ulaganjem truda $u$ podučavanje djeteta vještinama za život: „Moja uloga kao majka da ga vodim i naučim neke osnovne stvari kao što je higijena pa nadalje." (1), „Moja uloga kao oca je da dječaka spremam njegovim sposobnostima u uključivanje za danji život" (7). U izjavama je jedna majka usmjerena na podučavanje djeteta u vođenju brige o sebi, dok se u očevoj ulozi ističe 
svijest o važnosti očinske figure za odrastanje dječaka te poučavanje vještinama koje će mu biti potrebne u životu. Požrtvovno roditeljstvo sudionici ističu kao vlastitu odgovornost u skrbi za dijete: „Ja očekujem od sebe da ga izvedem na pravi put“ (1), „Moje dijete je moja odgovornost, veliku ulogu imam u životu mojeg djeteta, mislim da se maksimalno trudim u podizanju i odgoju." (2), „Moja uloga oko djeteta je maksimalna odgovornost, smatram da sam dala sve od sebe, što se tiče u njegovom odgoju, odrekla sam se puno stvari u životu da bi bila dobra majka." (3). Sva tri iskaza odnose se na majke, što upućuje na tradicionalno veću posvećenost majki nego očeva. Iako se iz nalaza ne može tumačiti količina brige njihovih supružnika o djeci, ipak su iskazi jasne indikacije da majke sebi pripisuju visoku odgovornost za odgoj djeteta, s čim je povezano žrtvovanje drugih područja svoga života. Istraživanja potvrđuju kako majke djece s kroničnim bolestima provode manje vremena u aktivnostima s djecom i aktivnostima slobodnoga vremena te imaju manje rekreacijskih aktivnosti u odnosu na majke djece bez takvih teškoća (Quittner i dr.). Rezultati istraživanja Pelchat, Lefebvre i Perreault (2003) o samopercpeciji majki i očeva djece s teškoćama u razvoju pokazuju kako su majke više usmjerene na propitivanje svojih roditeljskih vještina i postavljaju sebi veća očekivanja, osobito kada se radi o skrbi djeteta, što im povećava razinu stresa. Rowbotham, Carroll i Cuskelly (2011) pokazali su kako majke provode dnevno oko 40 \% više vremena u aktivnostima koje se odnose na skrb o djetetu nego očevi. Dio majki to je objasnio time što same preuzimaju na sebe veću brigu jer očevi rade izvan kuće. Međutim, čak i zaposlene majke preuzimaju veći dio brige o djetetu od očeva. No, požrtvovno roditeljstvo i posvećenost odgoju djeteta imaju i pozitivnu konotaciju u izjavama sudionika ovoga istraživanja. Moguće je to tumačiti time da se roditelji osjećaju sposobno u svojoj ulozi. Kako navode, radi se o tome da se trude biti dobri roditelji i odgojiti dijete za budući samostalni život. Milić-Babić i Laklija (2013) navode kako je za doživljaj roditeljstva ključan upravo roditeljski osjećaj sposobnosti za roditeljsku ulogu, odnosno u literaturi se naglašava da su osjećaj sposobnosti u ulozi roditelja i zadovoljstvo 
ispunjavanjem roditeljske uloge pozitivno povezani (usp. Belchic, 1995, prema Milić Babić - Laklija, 2013).

\subsubsection{Briga o djetetovim potrebama}

Roditelji su prve osobe zadužene za brigu o djetetovim potrebama još od rođenja. Sudionici ovoga istraživanja ističu svoju ulogu u pružanju emocionalne sigurnosti djetetu: „Moja uloga kao majke da sam njezin oslonac i sigurnost da joj budem najbolji prijatelj, oslonac na koji uvijek može računati i ljubav koju joj dajem, moja uloga da se osjeća voljeno“" (4), „Moja uloga je kao majka da sam uvijek uz nju da razgovaramo.“ (6), „Svoju ulogu doživljavam kao brižni otac, naročito kada je riječ o razgovoru s djetetom." (5). Dvije majke i jedan otac vide važnost pružanja emocionalne sigurnosti djetetu te tomu doprinose vlastitim angažmanom kroz razgovor s djetetom i verbaliziranjem ljubavi i potpore. Brigu za materijalnu sigurnost ističu dva sudionika, jedna majka i jedan otac: „...da joj priuštim osnovne materijalne stvari ... (4), „Otac koji je tu da priušti da sve ima da se osjeća sigurno." (5).

Materijalna sigurnost je tema koja je nezaobilazna u razgovoru s roditeljima djece $s$ teškoćama u razvoju s obzirom na činjenicu da invaliditet $\mathrm{u}$ obitelji iziskuje dodatna financijska sredstva, naravno ovisno o vrsti i stupnju teškoće koju dijete ima (usp. Leutar - Oršulić, 2015). Brigu za zdravstveno stanje iskazala je jedna sudionica i time dopunila popis zadataka koje roditelji preuzimaju u životu djeteta: „Uloga mi je da redovito ide na kontrole." (6). Iako se radi o malome broju sudionika, rezultati ovoga istraživanja ukazuju na mijenjanje tradicionalne uloge oca koji isključivo financijski zbrinjava obitelj i majke koja je primarno skrbnica. Očevi i majke pridaju sebi odgovornost za materijalnu sigurnost djeteta kao i za zadovoljavanje emocionalnih potreba.

Iskazi roditelja ukazuju na pozitivan doživljaj roditeljstva koji se očituje iskazivanjem brige za djetetove potrebe kroz pojmove ljubavi, brižnosti, podrške i prijateljstva. Heiman (2002) tako navodi kako roditelji uz stres opisuju i pozitivni dio roditeljstva kao što su osjećaj radosti, optimizma, snage, prihvaćanja i sl. Za odgovarajuću brigu o djetetovim 
potrebama potrebno je prihvaćanje djetetove dijagnoze. Feniger-Schaal i Oppenheim (2013) su u istraživanju s majkama uvidjeli kako postoji povezanost između razine majčina prihvaćanja dijagnoze i njezine osjetljivosti za dijete. Razrješavanje osjećaja vezanih za djetetovu dijagnozu poboljšava majčinu mogućnost da osjetljivo reagira na djetetove potrebe i signale za vrijeme interakcije. Dakle, osim negativnih iskustava nakon stresnoga procesa suočavanja s dijagnozom djeteta, roditelji iskazuju kako postoji i pozitivna strana. Zadržavaju nadu, bore se da osiguraju djetetovo preživljavanje i razvoj, govore o djetetu s ljubavlju, divljenjem i optimizmom (usp. Kearney - Griffin, 2001).

\section{Zaključak}

ADHD je složeno stanje koje predstavlja izazov za dijete, roditelja i sve druge koji su aktivno uključeni u svakodnevno socijalno okruženje, a u kombinaciji s intelektualnim teškoćama situacija se znatno usložnjava. Dosadašnja istraživanja ukazuju na povećanu razinu stresa kod roditelja djece s ADHD-om, a situacija je još složenija kada je ADHD dijagnoza uz još jednu ili više drugih razvojnih teškoća kod djeteta.

Rezultati pokazuju kako iskustva roditelja u našem okruženju ne odstupaju bitno od iskustava roditelja u razvijenijim zemljama. Čini se da je svakodnevna borba roditelja sa stigmom i specifičnim problemima suživota s djetetom sa simptomima intelektualnih teškoća i ADHD-a prisutna u različitim društvenim kontekstima, neovisno o stupnju razvijenosti zemlje. Roditelji i u ovome istraživanju opisuju prihvaćanje dijagnoze kao procesa obilježena neugodnim emocijama kao što su uznemirenost, tuga, razočaranje, strah i zabrinutost. U suočavanju s novonastalom situacijom ističu mobilizaciju vlastitih mehanizama suočavanja kao što su posvećenost skrbi za dijete, religioznost i samoohrabrivanje. Socijalna podrška koja je za obitelj i roditelje neprocjenjivo važna uobličena je u postojanje formalnih izvora podrške u lokalnoj zajednici koju roditelji koriste i procjenjuju vrlo važnom. Lokalne udruge još su jednom prepoznate kao akteri koji doprinose kvaliteti života roditelja time što omogućuju podršku kao i ostale ustanove u lokalnoj zajednici i stručnjaci s 
kojima roditelji dolaze u kontakt. Međutim, obiteljska podrška pokazala se zastupljenijom i samim time i dostupnijom većemu broju roditelja, a odnosi se na članove uže obitelji, tj. roditelje, supružnike, djecu i braću. Dio roditelja pronalazi podršku i u široj okolini, no kada su u pitanju obitelj i okolina, rezultati su dvojaki, Naime, dio roditelja iskazuje i iskustvo nedostatka socijalne podrške koji su doživjeli kroz izbjegavanje od osoba iz okoline kao i nepodržavajuću obitelj. Svoju ulogu u djetetovu životu definiraju kroz posvećenost odgoju, kroz požrtvovnost i podučavanje djeteta vještinama koje će mu biti potrebne za život. Identificiran je i drugi segment uloge roditelja, a to je odgovornost za zadovoljavanje djetetovih potreba za emocionalnom i materijalnom sigurnošću te brigom za zdravstveno stanje.

$\mathrm{Na}$ temelju rezultata istraživanja može se zaključiti kako je potrebno raditi na senzibilizaciji javnosti za brojne probleme $\mathrm{s}$ kojim se susreću djeca s intelektualnim teškoćama. Zajednica koja nije dovoljno informirana ima tendenciju djecu s ADHD-om karakterizirati kao „neodgojenu djecu“. Roditeljima su usluge i podrška u lokalnim zajednicama nerijetko nedostupne ili nezadovoljavajuće, stoga je potrebno ulagati stalne napore $\mathrm{u}$ kreiranje usluga u skladu s potrebama obitelji djece $\mathrm{s}$ ADHD-om i drugim razvojnim teškoćama. Kada se govori o podršci roditeljima, važna je interdisciplinarna suradnja svih stručnjaka (psihologa, edukacijskih rehabilitatora, socijalnih radnika i dr.), obitelji i škola kako bi postojeće intervencije imale uspjeha.

Također je važno ukazati na određena ograničenja provedenoga istraživanja koja se $\mathrm{u}$ prvome redu mogu odnositi na mali broj sudionika. Naime, za potrebe ovoga istraživanja već u početku broj sudionika znatno je ograničen zato što se ADHD često ne prepoznaje kod djece te ostaje nedijagnosticiran (Hrelja-Bećirspahić - Nakić, 2014). Svakako mali broj sudionika onemogućuje generaliziranje rezultata na širu populaciju, no kvalitativna istraživanja traže odabir onih sudionika koji će biti najbolji informanti, odnosno koji će dati najviše informacija i pružiti najbolje razumijevanje predmeta interesa (usp. Creswell, 2007, 125). Dostupni informanti dali su uvid u svoja iskustva u svrhu istraživanja ovoga rada, a svakako bi bilo poželjno slično istražiti i u 
drugim dijelovima Bosne i Hercegovine i na većem uzorku. Također, bilo bi korisno da se buduća istraživanja usmjere na iskustva roditelja djece s ADHD-om koja nemaju pridruženih drugih razvojnih teškoća.

\section{Literatura}

- Ahuja, Alka - Martin, Joanna - Langley, Kate - Thapar, Anita (2013),,Intellectual Disability in Children with Attention Deficit Hyperactivity Disorder", The Journal of Pediatrics, Elsevier, god CLXIII, br. 3, str. 890 - 895, <https://www.sciencedirect.com/ science/article/pii/Soo22347613002503>, (16 II 2020).

- Bartolac, Andrea (2013) „Socijalna obilježja svakodnevnog života djece i mladih s ADHD-om, te njihovih roditelja", Ljetopis socijalnog rada, Zagreb, god. xx, br. 2, str. $269-300$.

- Braun, Virginia - Clarke, Victoria (2008) „Using thematic analysis in psychology”, Qualitative Research in Psychology, Taylor \& Francis, god III, br. 2, str. $77-101$

- Chang, Mei-Ying - Mcconkey, Roy (2008) „The Perceptions and Experiences of Taiwanese Parents who have Children with an Intellectual Disability", International Journal of Disability, Development and Education, Taylor \& Francis, god. LV, br. 1, str. 27 - 41.

- Cochran, Moncfrieff - Walker, Susan K. (2005) „Parenting and Personal Social Networks", Luster, ToM - OKagaki, Lynn, Parenting: An Ecological Perspective, Routledge, New York, str. 235 $-273$

- Cosser, Catherine Phyllis (2005) Raising a child with attention deficit hyperactivity disorder: a parents' perspective, doktorska disertacija,University of South Africa, <https://core.ac.uk/download/pdf/43165708.pdf>, (14, III 2020).

- CREswell, JoHN W. (2007) Qualitative inquiry and research design: Choosing among Five approaches, 2 izd., Sage, Thousand Oaks.

- Dosreis, Susan - Barksdale, Crystal L. - Sherman, Andrea - Maloney, Kate- Charach, Alice (2010) „Stigmatizing 
experiences of parents of children with a new diagnosis of ADHD", Psychiatric Services, god. LXI, br. 8, str. $811-816$.

- Feniger-Schaal, Rinat - Oppenheim, David (2013) „Resolution of the diagnosis and maternal sensitivity among mothers of children with Intellectual Disability", Research in Developmental Disabilities, Elsevier, god. XxxIV, br. 1, str. 306 - 313.

- Graungaard, Anette Hauskov - Skov, L. (2007) „Why do we need a diagnosis? A qualitative study of parents' experiences, coping and needs, when the newborn child is severely disable", Child: Care, Health and Development, Wiley, god. XXIII, br. 3, str. 296 -307 .

- Gupta, Ashum - Singhal Nidhi (2004) „Positive perceptions in parents of children with disabilities", Asia Pacific Disability Rehabilitation Journal, god. XV, br. 1, str $22-35$.

- Hallberg, Ulrika - Klingberg, Gunilla - Reichenberg, KJell - Möllerhallberg, Anders (2008) „Living at the edge of one's capability: Experiences of parents of teenage daughters diagnosed with ADHD", International Journal of Qualitative Studies on Health and Well-being, Taylor \& Francis, god. III, str. 52 -58 .

- Heiman, Tali (2002) „Parents of Children with Disabilities: Resilience, Coping, and Future Expectations", Journal of Developmental and Physical Disabilities, Springer, god. xIv, br. 2, str. $159-171$.

- Heiman, Tali - Berger, Ornit (2008) „Parents of children with Asperger syndrome or with learning disabilities: Family environment and social support", Research in Developmental Disabilities, Elsevier, god. XXIX, br. 4, str. $289-300$.

- Hrelja-Bećirspahić, Berminka - Nakić, Taida (2014) ADHD (deficit pažnje/hiperaktivni poremećaj) u uzrastu od 6 do 12 godina, <http://www.mentalnozdravlje.ba/uimages/istrazivanja/adhd. pdf $>$, (12 III 2020). 
- Hughes, Lesley - Cooper, Paul (2009) Razumijevanje djece $s$ ADHD sindromom i pružanje potpore: strategije za nastavnike, roditelje i ostale stručnjake, Naklada Slap, Jastrebarsko.

- Jensen, Peter S. - Martin, David - Cantwell, Dennis P. (1997) „Comorbidity in ADHD: Implications for research, practice, and DSM-V", Journal of the American Academy of Child $\mathcal{E}$ Adolescent Psychiatry, Elsevier, god. xxxvi, br. 8, str. 1065 - 1079.

- Kandel, Isack - Merrick, Joav (2003) "The Birth of a Child with Disability. Coping by Parents and Siblings“, The Scientific World Journal, Hindawi Publishing Corporation, god. III, str. 741 -750 .

- Kearney, Penelope M. - Griffin, Tim (2001) „Between joy and sorrow: being a parent of a child with developmental disability", Journal of Advanced Nursing, Wiley, god. XxxIv, br. 5, str. $582-$ 592.

- Larson, Kandyce - Russ, Shirley A. - Kahn, Robert .S. Halfon, Neal (2007) „Patterns of Comorbidity, Functioning, and Service Use for US Children With ADHD", Pediatrics, American Academy of Pediatrics god. CXXVII, br. 3, str. $462-470$.

- LEUTAR, ZDRAVKA - ORŠULIĆ, VIOLETA (2015) „Povezanost socijalne podrške i nekih aspekata roditeljstva u obiteljima s djecom s teškoćama u razvoju", Revija za socijalnu politiku, Zagreb, god. XXII, br. 2, str. $153-176$.

- Leutar, Zdravka - Ogresta, Jelena - Milić Babić, Marina (2008) Obitelji osoba s invaliditetom i mreža podrške, Pravni fakultet Sveučilišta u Zagrebu, Zagreb.

- Milas, Goran (2009) Istraživačke metode u psihologiji i drugim društvenim znanostima. Naklada Slap, Zagreb.

- Milić Babić, Marina - LaKlija, Maja (2013) „Strategije suočavanja kod roditelja djece predškolske dobi s teškoćama u razvoju", Socijalna psihijatrija, Medicinska naklada, god. XLI, br. 4, str. 215 -225 . 
- McCabe, Helen (2008) „The Importance of Parent-to-Parent Support among Families of Children with Autism in the People's Republic of China", International Journal of Disability, Development and Education, Taylor \& Francis, god. LV, br. 4, str. $303-314$.

- Mcconnell, David - Savage, Amber (2015) „Stress and Resilience Among Families Caring for Children with Intellectual Disability: Expanding the Research Agenda", Current Developmental Disorders Reports, Springer, god II, str. $100-109$.

- Merriam, Sharan B. (2009)Qualitative Research: A Guide to Design and Implementation. John Wiley \& Sons, San Francisco.

- Moran, Patricia - Ghate, Deborah - Van Der Merwe, Amelia (2004) ,What works in parenting support? A review of the international evidence (RR574)" Department for Education and Skills, London <http://www.prb.org.uk/wwiparenting/RR574. pdf $>$, (23 III 2020).

- Neece, Cameron L. - Baker, Bruce L. - Crnic, Keith - BlacHER, JAN (2013) ,Examining the Validity of ADHD as a Diagnosis for Adolescents with Intellectual Disabilities: Clinical Presentation", Journal of Abnormal Child Psychology, Springer, god. XLI, str.597 - 612 .

- Pelchat, Diane - Lefebvre, Hélène - Perreault, Michel (2004) „Differences and similarities between mothers' and fathers' experiences of parenting a child with a disability", Journal of Child Health Care, Sage, god. viI, br 4, str. $231-247$.

- Peters, Kathleen - Jackson, Debra (2008) „Mothers' experiences of parenting a child with attention deficit hyperactivity disorder", Journal of Advanced Nursing, Wiley, god. LXv, br. 1, str. $62-71$.

- Quittner, Alexandra L. - Opipari, lisa C - Regoli, Mary JeAn, JACOBSEN, JeSSiCA - EIgEN, HowARd (1992) ,The Impact of Caregiving and Role Strain on Family Life: Comparisons between Mothers of Children with Cystic Fibrosis and Matched Controls", 
Rehabilitation Psychology, American Psychological Association, god. XXXVII, br. 4, str. $275-290$.

- Rowbotham, Michelle - Carroll, Annemaree - Cuskelly, MoniCA (2011) „,Mothers' and fathers' roles in caring for an adult with an intellectual disability", International Journal of Disability, Development, and Education, Taylor \& Francis, god. LVIII, br. 3, str. $223-240$.

- Schalock, Robert L. i dr. (2007) ,The renaming of mental retardation: understanding the change to the term intellectual disability", Intellectual and Developmental Disabilities, American Association on Intellectual and Developmental Disabilities, god XLV, br. 2, str. $116-24$.

- Seidman, Irving (2006) Interviewing as qualitative research: $A$ guide for researchers in education and the social sciences, Teachers College Press, New York.

- Sen, Esine - Yurtsever, Sabire (2007) „Difficulties Experienced by Families With Disabled Children", Journal for Specialists in Pediatric Nursing, Wiley, god. XII, br. 4, str. $238-252$.

- Strehle, Eugen-Matthias - Middlemiss, P. M. (2007) „Children with 4q-syndrome: The parents' perspective”, Genetic counseling, Springer, god. XVIII, br. 2, str. 189 - 199.

- Taylor, Deborah K. (1999) Impact of Attention Deficit Hyperactivity Disorder (ADHD) on Parents and Children: What are the Lived Experiences of a Parent with a Child with ADHD, magistarski rad, Grand Valley State University, Allendale, MI <http://scholarworks.gvsu.edu/theses/461>, (22 II 2020).

- Theule, Jennifer - Wiener, Judith - Tannock, Rosemary Jenkins, Jennifer M. (2010) ,Parenting Stress in Families of Children With ADHD: A Meta-Analysis", Journal of Emotional and Behavioral Disorders, Sage, god. Xx, br. 10, str. $1-15$.

- Timmermanis, Victoria - Wiener, Judith (2011) „Social Correlates of Bullying in Adolescents With Attention-Deficit/ 
Hyperactivity Disorder" Canadian Journal of School Psychology, god. XXVI , br. 4, str. $301-318$.

- Velki, Tena - Dudaš, Manuela (2016) „Pokazuju li hiperaktivnija djeca više simptoma agresivnosti?", Ljetopis socijalnog rada, Zagreb, god. XXIII, br. 1, str. $87-121$.

- Willingham-Storr, Gemma Louise (2014) „Parental experiences of caring for a child with intellectual disabilities: A UK perspective", Journal of Intellectual Disabilities, Sage, god. XVIII, br. 2, str. $146-158$.

- Yousefia, Shakila - Far,Soltani Atefeh - Abdolahianb, EBRAHIM (2011) „Parenting stress and parenting styles in mothers of ADHD with mothers of normal children", Procedia - Social and Behavioral Sciences, Elsevier, god. xxx, str. 1666 - 1671. 
Preliminary communication

Received on October 19, 2019

Maja Nižić - Tanja Penava - Marijana Mutabdžić

University of Mostar, Faculty of Humanities and Social Sciences Županja

\section{EXPERIENCES OF THE PARENTS OF CHILDREN WITH INTELLECTUAL DISABILITIES IN COMORBIDITY WITH ADHD}

\section{Abstract}

In Bosnia and Herzegovina little is known about experiences of the parents whose children have intellectual disabilities combined with the presence of ADHD. The aim of this research is to get an insight into experiences of those parents through research questions referring to the process of accepting the diagnosis, support experiences and experiencing their role in a child's life. Analysis of the results showed that parents experienced unpleasant emotions and uncertainty while facing the diagnosis. They mobilize different personal mechanisms for that purpose. Formal sources of support, family and support of the wider environment are important for facing everyday challenges and some parents do not have enough of social support. They see their role through dedication to nurturing of the child and satisfying the child's needs. On the basis of the research results it can be concluded that it is necessary to work on raising the awareness of the public about numerous problems of the parents whose children have intellectual disabilities and ADHD as well as provide better and more accessible services that will be crated according to the needs of those families.

Keywords: parents of children with intellectual disabilities; ADHD; support; facing 